\title{
From semiotic exegesis to contextual ecclesiology: The hermeneutics of missional faith in the COVIDian era
}

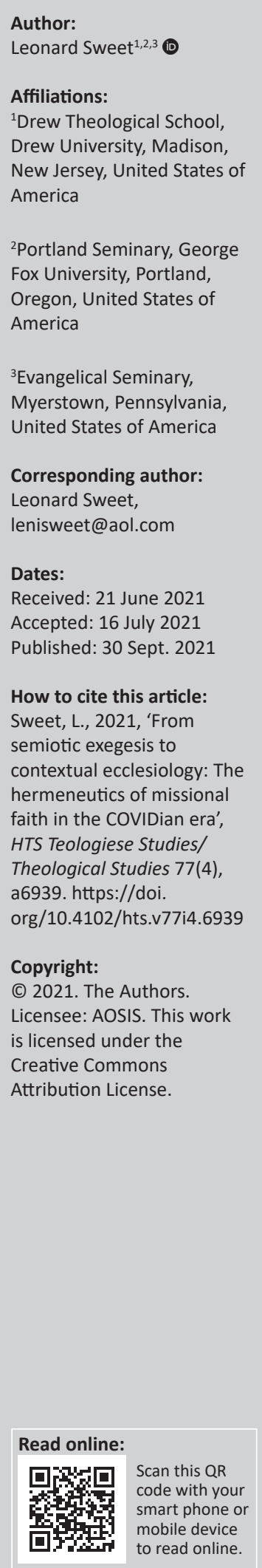

This essay uses the global impact of the Coronavirus as a heuristic semiotic for exploring the future of the church. Unlike the pandemic of 1918, which left few dents on the world's economic, social, and cultural systems, almost all the nations of the world have passed laws and implemented procedures that are only comparable to world wars in their impact on entire populations. Nations are acting in unison, but not in unity. This post-COVID, postCorona world is the 'time that is given' to the church. But it will not be a post-pandemic world. We may become COVID-proof, but we will never be pandemic-proof. There is no pre-COVID reset. There is only risk assessment from natural extinction risks to existential dangers of our own creation that are catching up to us (climate change, GRAIN [genetic engineering, robotics, artificial intelligence $\{\mathrm{AI}\}$, info-tech, nanotechnology]). Disruption is the new status that is never quo; stability is the new abnormality; global cataclysm is the ever-present peril. The only way to prepare for a future of constant 'the end of the world as we know it?' moments is by developing a high Contextual Quotient (CQ), and deepening our Contextual Intelligence (CI) so we can choose 'the next right thing' in a world of volcanic volatility.

Contribution: This essay frames the semiotics of a missional ecclesiology in the COVIDian wake from the hermeneutics of blessings not curses. What virtues might we expect to come out of a virus that is fast-forwarding the future, virtues that will shape the contours of Christianity. What if the pandemic is a shock treatment that is putting the world, and the church, back in a new and better equilibrium? What if there are goldmines on the other side of the landmines and minefields?

Keywords: COVIDian era; post-pandemic; semiotics; new monasticism; iconomic.

In 1941, biochemist Alexander Todd visited the Defence Research Establishment at Porton, England, to see a demonstration of a new chemical weapon to be used against tanks. Afterwards he commented:

'I proceeded to the bar where - believe it or not - there was a white-coated barman who was not only serving drinks but also cigarettes!'

'I hastened forward and rather timidly said, "Can I have some cigarettes?"'

“"What's your rank?" was the slightly unexpected reply.'

'“I am afraid I haven't got one," I answered.'

'Nonsense - everyone who comes here has a rank.'

'I'm sorry but I just don't have one.'

"'Now that puts me in a spot," said the barman, "for orders about cigarettes in this camp are clear twenty for officers and ten for other ranks. Tell me what exactly are you?"'

'Now I really wanted those cigarettes so I drew myself up and said: "I am the Professor of Chemistry at Manchester University."'

'The barman contemplated me for about thirty seconds and then said, "I'll give you five."'

Todd, who won a Nobel Prize in Chemistry in 1957, added, 'Since that day I have had few illusions about the importance of professors!' (Todd 1983).

That story came to mind when Yale physician/sociologist Nicholas Christakis, from his ivytowered Olympian omniscience, opined about the number one word of 2020: Pandemic. For some, navigating a 'the world has gone mad' pandemic pandemonium inspires chagrin, contrition

Note: Special Collection: From timely exegesis to contemporary ecclesiology: Relevant hermeneutics and provocative embodiment of faith in a Corona-defined world - Festschrift for Stephan Joubert, sub-edited by Willem Oliver (University of South Africa). 
and humility. For others, 'the world has gone mad' moments like the global COVID-19 pandemic lead to 'stop the world I want to get off' survivalist strategies and opt-out escapes. For others, it evokes 'know it all arrogance'. Professor Christakis concluded that the way the United States handled the whole COVID-19 pandemic was so ignorant and unenlightened, 'if the country were a student in one of my courses, I would not hesitate to hand it an $\mathrm{F}^{\prime}$ (Christakis 2020).

This essay will use the global impact of the coronavirus as a heuristic semiotic for exploring the future of the church. Unlike the pandemic of $1918,{ }^{1}$ which left few dents on the world's economic, social and cultural systems, almost all the nations of the world have passed laws and implemented procedures that are only comparable to world wars ${ }^{2}$ in their impact on entire populations. ${ }^{3}$ Nations are acting in unison, but not in unity. They are all basically doing the same thing, but without collaboration and cooperation. The first global threat of the 21st century showcased a global response of every nation for itself, unready and unprepared.

If so nations, how much more so people feel overwhelmed, under water, and unprepared than thinking that they know precisely how to handle a COVID-19 pandemic and postcorona world. Accordingly, the start to any missional faith amidst a pandemic pandemonium is the embrace of two prickly assumptions, one internal and one external.

First, there is the acceptance of this COVIDian missional moment as a divine appointing and anointing. In the words of the Chandler Moore song, Built For This (Moore 2020), 'There is no battle I'm not built for'. In the providence of God, we are in this moment by an arranged marriage between the God who made us and the mission field in which we find ourselves - a 21st-century world with 22nd-century children and grandchildren.

In Tolkien's The Lord of the Rings (1954), a poignant conversation takes place between Frodo and Gandalf. Frodo said, 'I wish the ring had never come to me. I wish none of this had happened.' Gandalf replied:

So do all who live to see such times, but that is not for them to decide. All you have to decide is what to do with the time that is given to you. (Tolkien 1954)

1.The so-called 'Spanish flu' of 1918 was a type of pneumonia that spread from birds to humans.

2.The comparison of the pandemic to a war story is not gratuitous on my part. CNN President Jeff Zucker told his staff to 'Stay on the COVID War story.' During COVID's 'war story' CNN's ratings soared $120 \%$. As the old saying goes, 'When war drums beat, ... the masses believe what they are being sold and obey their leaders' marching orders'.

3.Draconian Regulations imposed by governments included

1. Police enforced curfews from 20:00 to 05:00

2. No wedding or funeral gatherings.

3. Schools closed except online classes.

3. Schools closed except online classes.
4. Only one person per household allowed to leave home once a day to pick up Only one person per household allowed to leave home once a day to pick up
essential goods. When going out, you must stay within a 3.1 mile radius of your home, no further.

5. All non-essential industries like tourism, the $\# 1$ industry in the world, shutdown and grounded.
Volcanoes and caves are some of the most dramatic settings for turning points in the Scriptures. There is Moses and the burning bush, Moses and the ten (10) commandments, Elijah fleeing to Mount Horeb after receiving a death threat from Jezebel and then hiding in a cave while hearing the voice of God speaking in the thunder, lightning, fire, and 'thin silence' (1 Ki 19:1-18). God asks Elijah: 'What are you here for?' Elijah then tells God what he has done for him, and what he has been through, and what it has cost him. Essentially, Elijah is saying, 'How can you even ask me that question after what I've done for you, God?' But then God throws Elijah a semiotic curve. 'Maybe you are here for not what you thought you were here for? Maybe you are here to find a new direction for your life, and to raise up your successor Elisha.'

Maybe 'what we are here for' and what the church has been called to do for this moment is something different than the standard 'ministry' that it thinks the church has been given? Maybe, like the Magi, the church is being called to return home by a different route we came?

This post-COVID, post-corona world is the time that is given' to the church. However, it will not be a post-pandemic world. Pandemic pandemonium is the 'new norm', as we should have suspected from the viral visitations of the last few decades from SARS, MERS, Ebola, HIV, Zika, and H1N1. ${ }^{4}$ There is one certainty in the missional context to which the church is called: in the future, there will be new plagues and new pandemics, more viruses and more outbreaks (Honigsbaum 2020). We may become COVID-proof, but we will never be pandemic-proof. There is no pre-COVID reset. There is only risk management from natural extinction risks and existential dangers of our own creation that are catching up to us (climate change, [GRAIN] genetic engineering, robotics, artificial intelligence $\{\mathrm{AI}\}$, info-tech, nanotechnology]). ${ }^{5}$ Disruption is the new status that is never quo; stability is the new abnormality and global cataclysm is the ever-present peril. ${ }^{6}$

All meals are now eaten on volcanoes (Sweet 2019), with items on the menus and pricings of the meals that have no rhyme or reason. For example, in 2019, pennies made up 59\% of the coins minted in the United States. Yet, they cost the US mint $\$ 70$ million more in 2018 than the coins were worth. A one cent coin costs two cents to produce, but we still make

4.In comparison to some of these other viruses, COVID-19, which is technically called SARS-CoV-2 virus, takes a mild form in most cases, but in the elderly and SARS-CoV-2 virus, takes a mild form in most cases, but in the elderly and
compromised, can be very deadly. It spreads among people who hardly know they compromised, can be very deadly. It spreads among people who hardly know they
have it or simply don't know they have it, but it latches on to those with underlying health problems with deadly force. The H1N1 influenza virus killed 50 million people, with a preference for the young who could not oxygenate their tissues fast enough and turned blue and died almost overnight. HIV caused 30 million fatalities through AIDS. But HIV doesn't kill outright, but over time slays the immune system. The coronavirus had a precedent, the SARS pandemic in 2003, which was also a coronavirus that originated in China. But it had only 774 fatalities.

5.For more on our GRAIN-y future, see my Rings of Fire: Walking by Faith Through a Volcanic Future (Sweet 2019). No one seems to want to talk about the recent revelations that deadly and highly communicable viruses have been engineered in revelations that deadl name of science.

6.It's time to learn this acronym: AMR (anti-microbial resistance). It will be on everyone's lips and too many death certificates in the next 20 years. Seventy per cent $(70 \%)$ of chickens sold by supermarkets are infected with the poisonous (to humans) bug campylobacter, yet there is no barrier to selling them. 
them. In 2008, we crossed a Rubicon into cuckoo land: it was the year the US government began borrowing nearly 50 cents for every dollar it spent (Sullum 2009:8).

The only way to prepare for constant 'the end of the world as we know it?' moments is by developing a high (CQ) contextual quotient, developing and deepening our (CI) contextual intelligence so that we can choose 'the next right thing' in a world of volcanic volatility. COVID-19, the first global black swan, taught us that one virus can change the face and future of the world and the church - in one fell swoop.

COVID has also taught us that the looking glass of one evil can pinpoint and magnify evils that were lurking in the background all along. Though, COVID-19 will not be the last. The sudden appearance of black swans, nine hundred Pound Guerillas, Dropping Dinosaurs, Runaway Trains, Carrington Events, Wild Cards or a collapsing House of Cards (cf. Sweet 2019; Tainter 1990; Taleb 2007) will usher in successive turning points that require overnight pivots (e.g. from classroom to virtual, from dine-in to take-out), enduring resilience and fluid reckonings. Contextual intelligence (Sweet \& Beck 2021) is the semiotic ability to enter in, read, and speak to the moment you are in with guts, gusto, and grace. $^{8}$

Second, the whole world has been put under house arrest. We have retreated to our shells and lived in sheltered cocoons. When we come out, we will not be the same people that went in. We are a lockdown generation. Our kids (Zoomers?) will have this lockdown - both the physical and the emotional - as the defining moment of their lives. There will be a comet's tail of long-term consequences.

When we come out of our shells, we will experience shellshock.

A lockdown mentality is a closed down mind, body and spirit. The missional focus of the church is treating people with post-traumatic stress disorder (PTSD). When there is a collective trauma, especially a lingering trauma, people stop trusting each other. The virus of fear can be worse than the crisis-virus itself. We are a people hiding in dungeons and living in high dudgeon (easily offended). The lockdown effect generates a dungeon and dudgeon generation.

When people are wracked in fear, facts and data do not matter. We are less willing to take risks or trust professionals. Unable or unwilling to think for themselves, people either put their minds in neutral and let politicians shift the gears, or treat seers with sneers and dismiss the press as 'presstitutes'. Inward-looking and self-reliant, not outwardfocused and resilient, faith becomes more about protection

7.The 1-2 September 1859 "Carrington Event" was a powerful geomagnetic storm during solar cycle 10. A solar coronal mass ejection hit Earth's magnetosphere and induced the largest geomagnetic storm on record. A Carrington Event would take out all the transformers, which doesn't sound so armageddonish unless you realise that all nuclear power plants depend on electricity to keep them from becoming a
nuclear volcano.

8.'Rhema' is the prophetic task of speaking a specific message to a given time and clime. God's message spoken to the moment is a rhema. than providence, safety than trust, barricades than frontlines. When faith becomes transactional, it is the opposite of what makes faith 'faith'.

In the shut-in economy or huddle economy of circling wagons, there is a resurgence of survivalism, apocalypticism, belligerent nationalisms, and burgeoning tribalisms. We are already witnessing the emergence of new anti-establishment, antielitist movements and parties: anti-medicine, ${ }^{9}$ anti-media, anti-government, anti-church, anti-business, and antieducation. It is not unrealistic to be more afraid of what's ahead than what's going on in the midst of the pandemic.

The worldwide widening of economic inequality is bringing back a new feudal system on a global level of extreme haves and extreme haves-not. Harvard economist, Raj Chetty, has found that absolute mobility (the chance that a child will go on to earn more than their parents) has dropped in the United States from $90 \%$ to $50 \%$ (The Economist 2020d:20). Sixty two per cent $(62 \%)$ of the people in the United States were not affected financially by COVID-19. Thirty eight per cent (38\%) of US Americans suffered severe financial devastation from COVID-19. In other words, the rich are getting richer faster, while the rest are entering into a deep depression - financially, physically, spiritually, and morally. In fact, to mandate two meters distancing and the constant washing of hands can be a death sentence when $25 \%$ of the world's 7.8 billion population has no access to running water and adequate sanitation. ${ }^{10}$ In the words of Rowan Williams, 'Perhaps we have had our eyes opened to who is least safe in our [global] neighborhood' (Williams 2021).

Post-COVID, the problem of inequality even gets more pressing than before and will transcend political divides. The notion that inequality is a necessary evil to a growing economy will no longer be palatable to either the left or the right. Investment strategies that take into account inequality and 'climate emergency' (Pope Francis) will expand to 'equality impact investments'. However, the church, itself being a multinational corporation, will be forced to scrutinise itself to see how its own actions (like what it pays its janitors and office staff, including missing health benefits) widen the gap.

After the pandemic, what will stick and what will slip back? One thing that will stick is the psychological scarring. It could last for decades. The legacy of lockdowns, maskings, 9.The number one killer in the Us? Not Cancer. Not heart disease. But iatrogenic illness, where the cure is more deadly than the disease.

10.A Johns Hopkins University study published in The Lancet and funded by the Gates Foundation revealed that the global shutdown of economies by governments has created massive suffering to millions of children worldwide. Its first paragraph reads, in part: 'In weighing their options, policy makers must consider not only the immediate health effects of the pandemic but also the indirect effects of the pandemic and the response to it. An analysis of the 2014 outbreak of Ebola virus in west Africa showed that the indirect effects of the outbreak were more severe than the outbreak itself' (Robertson et al. 2020:901). The paragraph goes on to remind the outbreak itself' (Robertson et al. 2020:901). The paragraph goes on to remind us that the unprecedented global social and economic crisis triggered by the COVID-19 pandemic 'poses grave risks to the nutritional status and survival of young children in low-income and middle-income countries (LMICs).' 'Of particula oncern is an unexpected increase in child malnutrition, including wasting, due to steep declines in household incomes; changes in the availability and affordability of nutritious foods, and interruptions to health, nutrition, and social protection services' (See Robertson et al. 2020:901-908). 
six-feet distancing and growing up under the COVIDian shadow will generate long-term social, emotional, and mental consequences, so terrible that they can only be imagined. ${ }^{11}$ An arms-length world may be more dangerous to live in than an arms-race world.

The French intellectual celebrity, Bernard-Henri Levy (yes, the French make celebrities out of their intellectuals), wonders if the advice to 'stay home, save lives' is an injunction to live a 'discount life knit together by absence, hygiene, and fear of oneself and others' (Levy 2020). When a child is taught to shrink back when others approach - 'Uh-oh ... people' the writing is being written on the wall. Walls will go up, freedoms will go down, a fear of flesh and new gnosticisms will rule robotic-sex roosts, and cultures will become increasingly authoritarian and Orwellian.

Composer/film-maker David Byrne is so concerned about the state of the world's spirit that he has established a 'reasons to be cheerful' website. One of the most creative churches in North America created its own press and innovation lab and chose as its first publication, Everything Is Gonna Be All Right: Devotionals For Faith and Encouragement (Hasley 2020). As someone who is a prayerful optimist but a natural pessimist, I am wrapping my critique in a comforter. I have decided to frame my semiotics of a missional ecclesiology in the wake of the COVID pandemic in the hermeneutics of blessings, not curses. What virtues might we expect to come out of a virus that is fast forwarding the future, virtues that will shape the contours of Christianity? What if the pandemic is a shock treatment which is putting the world and church back in a new and better equilibrium? What if there are goldmines on the other side of the landmines and minefields?

My soundtrack for this journey of finding silver linings in the COVIDian cloud is a ditty that I learned at summer camp called Count Your Blessings:

When upon life's billows you are tempest-tossed,

When you are discouraged, thinking all is lost,

Count your many blessings; name them one by one,

And it will surprise you what the Lord has done.

Count your blessings;

Name them one by one.

Count your many blessings;

See what God hath done. ${ }^{12}$

11.The costs of lockdowns are not just bankruptcies, but physical, emotional, and spiritual costs, with long-term mental and physical damage.

12.The rest of the verses go as follows:

Are you ever burdened with a load of care?

Does the cross seem heavy you are called to bear?

Count your many blessings; ev'ry doubt will fly,

And you will be singing as the days go by.

When you look at others with their lands and gold,

Think that Christ has promised you his wealth untold.

Count your many blessings; money cannot buy

Your reward in heaven nor your home on high.

So amid the conflict, whether great or small,

Do not be discouraged; God is over all.

Count your many blessings; angels will attend,

Help and comfort give you to your journey's end.
What would be the biggest nugget of discovery to come from the COVID goldmine after traversing the multiplicity of landmines and minefields? It surpasses yet encompasses all 15 'blessings' itemised below. So I mention it here at the beginning of our journey: 'The well-being and destiny of each one of us depends directly and indirectly on the wellbeing and destiny of all of us.'

Planet Earth is one 'ship', as Buckminster Fuller named it in 1964, 'Spaceship Earth'. ${ }^{13}$ There are no secret places where we can hide and do our own thing without impacting anyone else. We are tied together as one on this solo journey from life to death. When life is lived as soliloquy, not as colloquy, our horizon is full of obloquy at best, but oblivion more likely.

\section{Blessings to come out of the COVID curse}

\section{The building of the church is not a building}

It took a pandemic to kick the church out of its heretical notion that the ecclesia is an edifice. The confusion of the church with a building is fatal to mission, and the spell of the heresy has finally been broken.

A fall 2020 survey of 2500 Catholics in the United Kingdom reveals that $61 \%$ of the respondents say that they intend to revert back to physical services in their personal worship. However, that leaves a $40 \%$ loss in physical presence in worship. Less than half (49\%) said that they need a church building to fully express their faith, and only $26 \%$ thought that churches should stay open 'whatever the crisis'. In other words, three out of four Catholics in the United Kingdom were not opposed to the closing of church buildings (Dodd 2020:29).

I personally find certain church structures an enlivening resource to following the Via Crucis. In other words, a church building for me is not just a place where we worship God but a place with which we worship God. The truth is the modern church has seldom built spaces 'with which' we worship God, and those that have been built are exceptions that prove the rule. Steeples used to be signs of hope and healing to communities and to a nation. They have long ago lost that lustre and are now contentious signs of our public life and public spaces - but we will always privilege opening a front door to lifting a computer lid.

\section{There is a new front-door for the church: The Internet}

In a work from anywhere (WFA) world, we are learning to do church from anywhere (CFA). We're Zoomed, and the church is discovering Zoom is not Doom. Much of the church is proving that old Gutenberg dogs can learn new Zoom tricks.

13.Fuller's short book Operating Manual For Spaceship Earth was first published in 1969, but Fuller debuted the term in public in a 1967 speech and was using it privately with his colleagues as early as 1964 . 
Almost ever since Al Gore invented the Internet (or, in truth, Tim Berners-Lee made the adjustments that made the Internet accessible in the early 1990s), I have been calling for a digital ecclesiology - replete with all the attendant weeping, wailing, and gnashing of gums. Just as one crisis-virus did to clericalism in the Catholic Church what 2000 years of reformation couldn't, one global lockdown did to resistance to installing an Internet front door to every church what three decades of books, lectures, and seminars on Ecclesia Electronica failed to do (cf. Sweet 1994a, 1999a, 1999b, 2000, 2001, 2008, 2012). ${ }^{14}$

The church is now online. It is slowly learning to be the church in its now native digital culture. What was at first condemned as a 'front' for white privilege and elitism (progressives), and an affront to the faith once for all delivered to the saints (traditionalists), is now an ecclesiological imperative (Woods 2020). Jesus invites us continually into new relationships with reality, and a Twitter/TikTok, Google, Instagram, Facebook (TGIF) world is our new reality. The old Gutenberg reality has melted from exploding rings of fire (cf. Sweet 2019), and we walk a new world of magma-trends and lava-laden directions.

'Digital dignity' is the mantra of Microsoft CEO Satya Nadella. 'Digital dividends' is the mantra of entrepreneur and politician Andrew Yang. In 'digital dignity', people ought to have a say in how their information is being used and who is using it. In 'digital dividends', people ought to be compensated when their information brings huge dividends to companies, to oligopolies, and to the super rich.

It is time for the church to embrace digital indigeneity, a mantra for the missional church. The tracks and trajectories of colonialism are all over the online church today. Too often the church is merely imposing on digital culture what it is used to doing in print culture - inserting Gutenberg in a Google world - rather than incarnating church in a digital world. If the essence of colonialism is the imposition of your home culture on another culture, then the online presence of the church is more colonial than incarnational. For example, an online church means a 24/7 church, not a Sunday church or a 'nod to God hour' church. Online church means a pastor's space is now a studio, as the pastoral role moves study to office to studio (Sweet, McLaren \& Haselmayer 2003). Online church means a remote culture of learning and worship and community formation.

To be sure, online religious activity does not translate necessarily into deeper faith. Whether the bonds of faith are getting weaker or stronger from online worship is still to be determined. Downloads of Bible, prayer, and devotional apps are setting records, while one Pew survey found that one-quarter of the US Americans admit the pandemic has strengthened their faith (Gecewicz 2020). Upticks in Britons saying they have started to pray is startling in a nation proud of having left religion behind.

14.As President of United Theological Seminary from 1984 to 1995 , I created the first degree programme (Masters of Arts in Religious Communications) which specialised in computer ministry (under Professor Kenneth Bedell) and digital ministry (under Professor Dennis Benson).
Online worship is bringing back the Puritan era custom of 'gadding about', where parishioners would practice 'gadding to sermons', shuttling from one sermon to another. In Catholic circles today this is called 'mass travel', or 'mass hop' - the parish-hopping pursuit of best live-streamed worship. However, in Tudor and Stuart England, lay people would go en masse from one church to another just to hear the sermon. They would absent themselves from everything else in worship, fill the pews of a church for the sermon, then leave for another sermon as quickly as the sermon ended.

Keeping a missional focus will be a key issue for the future of the online church. How do we keep our people in a missional posture when the default setting is online? A missional focus will require all sorts of new creative stances and overtures.

Truly, we are not in Kansas anymore. We need to walk the yellow brick road together to this online reality of being church. Know that among those that sign up for that walk, there will be a tin man, scarecrow, the cowardly lion, and Toto - but we all make the journey together. And the journey is good evangelism: one poll in England found that one in twenty of those who interacted with religious livestreaming during the pandemic had never been to church before (Savanta: ComRes 2020).

\section{The original venue for the church was the home, and the centrepiece of ecclesia was the table. The post-COVID church of the future will bring back the table}

Just when we thought conventional notions of the home were on their way out - a place of security, safety, community suddenly they are coming back with jaws and teeth. We are learning home-based worship, as the early church celebrated it based on the Passover. In fact, the altar in the temple, also called the priestly 'table', is becoming once again the home table. The Gutenberg church learned to perfection the technique of 'tabling it', but it proved to be the wrong 'tabling' - the tabling of resolutions and not the tabling of relationships around food and conversation. Even the food industry has gone from marketing food as sensual and sexy with half-naked ladies licking their fingertips, to multi-racial extended families sharing a meal at the table. Catechesis cannot be outsourced to the church, but belongs in the home, headquartered at the table. The days of 'children's church' and the mentality of 'you teach my kids' are over.

The New York Times cultural commentator David Brooks (2019) has written about 'the technology of the table' and names the dinner table as 'the key technology of social intimacy' in communities rich in relationship:

It is the tool we use to bond, connect, and commit to one another. I've learned to never underestimate the power of a dinner table. It's the stage on which we turn toward one another for love like flowers seeking the sun. (p. 61)

The rediscovery of the Table as the ecclesiological Tree of Life will require what Hispanic cultures call sobremesa: afterdinner conversation around the table that makes dining an experience not just of physical food but of social friendship, 
intellectual stimulation and emotional satiation. In fact, a table-based ecclesia may introduce a two-grace tradition at the table. Before the meal, thanksgiving for the food prepared and about to be received. After the meal and before ending the sobremesa and leaving the table, thanksgiving for the conversation, companionship, and conviviality.

\section{Sozo Jesus: Jesus saves, Jesus heals}

'I have heard the joyful sound. Jesus heals. Jesus heals.'

Governments around the world told the religions of the world that faith is a non-essential service. How did the Christian church respond? 'Yes, you're right. We are nonessential'. The Church of England not only took to heart the government's bill of instructions but took them even further. Clergy were instructed not to enter their churches even for the purposes of streaming liturgies. The Archbishop of Canterbury published a manifesto promising 'not to get in the way' of the first responders and health professionals.

The church may come to regret this compliance and obeisance. For what does the church have to offer the nonchurch going public, the 'nones, dones, and somes' of the world? By acquiescing in our 'nonessentialism', and forgetting Jesus the Great Physician, we admit we add nothing of value to the public square.

The truth is just the opposite: the church is in the health and healing, wellness and wholeness business. The church is in the salvation business. Is there anymore MORE essential than health and healing, wholeness and wellness? Is there anything MORE essential than salvation?

When William Tyndale published the first English translation of the New Testament, translated directly from Greek texts in 1526, he used the term 'health' where we use 'salvation' to translate the Greek word 'sozo' (Sweet 1994b). The English term 'salvation' is itself derived from the medicinal term 'salve'. The terms for health, healing, wholeness and holiness are basically the same. Saviour is a healing term. Holiness is a 'final integration' of mind, body, and spirit, and the opening of connections between the human and divine. Sozo Jesus means Jesus is the Mediator of Ultimate Human Wellbeing.

Jesus' mission begins not with him preaching, or teaching, but healing. And the healing is often prefaced by the question, 'What can I do for you?' (Mk 10:50, Jn 5:6). Jesus does not use his healing to lift up his messiahship or to recruit disciples, but to simply help people and acknowledge their faith. Jesus begins his ministry with where people are: meeting and greeting them in the middle of their aches, ailments and anxieties. Jesus began his ministry showcasing a God who cares about the person and whatever the person cares about. ${ }^{15}$ There are 26 unique Jesus healings in the record, and Jesus healed each one uniquely.

15.American art historian Matthew (1999:92) states: 'Suddenly God was seen walkin among his people, touching, stroking, comforting, pressing his warm and life-giving
hands on them .... This was a radically new power, and the competition had nothing hands on them .... This was a radically new power, and the competition had nothing to match it.'
This identification with the sick and outcasts is partly what propelled the growth of early Christianity, as Jesus' disciples attended the sick and dying during the plagues that ravaged the Roman Empire in the second and third centuries (the Antoine Plague in the second, and the Plague of Cyprian in the third century). Dionysius 'The Great' of Alexandria (190-265), a student of Origen, wrote in 260:

Most of our brother Christians showed unbounded love and loyalty, never sparing themselves and thinking only of one another. Heedless of danger, they took charge of the sick, attending to their every need and ministering to them in Christ; and with them departed this life serenely happy. (cf. Eusebius 2004, Book 7, Sec. 22)

In the words of historian and sociologist Stark (2011):

Indeed, the impact of Christian mercy was so evident that in the fourth century when the emperor Julian attempted to restore paganism, he exhorted the pagan priesthood to compete with the Christian charities. (pp. 114-115)

During the plagues of his day, Protestant Reformer Martin Luther was haunted by the Great Judgement scene, where God says to some at the bar of justice, 'I was sick, and you did NOT visit me (Mt 25:33-46). Go to hell.' Have pastors become employees of an institution rather than deployers of the divine?

The health of the mind and spirit is as important as the health of the body. Do we really think that pastors serve best by remaining isolated from the people they were ordained to serve while hospital staff and medical professionals serve the sick and dying? Do we really think that sending the dying into eternity alone and unattended by their faith communities is a witness to the gospel ${ }^{16}$ By vacating the public square and dutifully retreating to our corners, the church made ecclesial much less clerical heroism impossible. The heroes and martyrs of COVID-19 are the doctors and nurses and 'essential workers' who keep hospitals running, grocery shelves stocked, mass transit functioning and sanitation crews and truck lines operating - the people Pope Francis calls 'the saints next door'. Audacious, formidable feats of service and selflessness can come from hospitals and public transport, banks, and supermarkets, but not from the church.

\section{'The dawn of the relationship era' (Levy \& Garfield 2012)}

For decades, futurists have been predicting 'the dawn of the relationship era'. In these prognostications, 'relationship' is conceived in interpersonal terms. We have now crossed the threshold of that 'relationship dawn', but the 'relational' aspect is not just with people but also with icons - narratives and images wrapped in soundtracks. The major economic and experiential currency of the future is iconomic.

The church, which has largely been in the proposition business in the late modern era, is finding itself inescapably

16.In six months, a virus first identified in Wuhan, China (December 2019) girdled the globe with more than 8.5 million confirmed cases in 188 countries, killing 472000 globe with more than 8.5 million confirmed cases in 188 countries, killing 472000 .
As bad as death is, these COVID-19 deaths occurred alone, without family or friends, just strangers attending them. 
in the relationship business. The laws, the propositions, the doctrines, are not the ends themselves; they are means to an end, and the end is a deeper relationship with God, ourselves, each other, and creation. The enforced shielding and 'staycation' have brought a much needed and deeper level of intimacy within marriages and families and friendships, even organisations. In Great Britain, for example, the National Health Service (NHS) has been such an embodiment and expression of the shared values of generosity, sacrifice, compassion, and solidarity, some are calling it the real 'National Church', more revered and respected than the established 'Church of England' (Rosen 2021).

People are wanting to live together again. Call them 'pods' or 'bubbles' or 'nuclear retreats', the fastest growing type of living arrangements are multi-generational households. Single-family households are on the way out (The Economist 2020e:59-60; cf. also DePaulo 2015), as the more the pandemic seems to push people apart, the more people find a way to keep together. In the wake of the pandemic, people are going to yearn for third places more than ever.

Home is the new castle, and home-working from a nonlinear workday will become the new norm. Employees will come into the office now and then and attend more corporate retreats, but soon you will be able to put on a VR headset and immerse yourself in a virtual office, bad fluorescent lighting and all.

Being in Christ means being in relationship with others and creation.

It is not just that we need to learn how to be 'present' online and in virtual space. We must relearn how to be 'present' to each other when we're physically present to each other. 'The big bold future', Laurence Scott predicts, 'will demand an evolution in how we think about what it means to be present, how we manifest bodily and virtually in the world' (Scott 2015:14,24,26). At the same time, the pandemic was plaguing the planet, scientists announced that brain cells and computers can now communicate through the Internet. Brains and computers can link over long distances through the 'Internet of NeuroElectronics', which promises to replace defective brain circuits with chips embedded with AI (Dalton 2020). Of course, it all depends on who gets to define what constitutes 'defective brain circuits'. Then there is the new computer software called Machine Inferred Code Similarity (MISIM), which can programme itself, leading us down the path of computers becoming autonomous with a next generation of computer hardware making it up as it goes along without human input (Intel Newsroom 2020).

The terms 'relationship' and 'presence', especially 'real presence', desperately need to be rethought and redefined in a world where every parent or grandparent is smitten when a child shows love for them by kissing the screen or hugging the iPad. Digital tools mediate relationships that can be as reciprocal and rewarding as 'real' places, as Zoom instructors are now discovering to their surprise (and exhaustion) as online 'classes' can be more relationally intense, richer, and rewarding than traditional classroom settings.
The church is going from being a 'production' to being a 'producer' - Less Hollywood and Hillsongs and more holiness and faith formation. It is increasingly less about the 'show' and more about the 'know' and the 'being known'. In the past, laity were expected to pay, pray, and obey. Then in the era of the mega-church, laity were expected to sit there, enjoy the performance, and pay for experience.

The post-COVID church is no longer a 'success theater'17 where you go to conferences to learn botox-like gimmicks to game the church's lame numbers and jimmy the appearances. Since we are not so busy running the church 'show', we have the time to look around and see the social catastrophes that are encircling us.

The pandemic has hit hardest the most vulnerable: the sick, elderly, poor, prisoners, homeless, compromised children and multigenerational families. The church can now also look at those who are outside church walls, and all the hunger, human rights abuses, inequities, lost jobs, and crashing small business. The 'staging' of the church will become less up front and leadership-focused and more backstage, side-stage, and pastoral.

Enforced solitude has taught us that 'shut in' time is not shut down time but rise up and shout out time. Maybe we could have learned something ahead of time from the 8 million people in the UK who live alone, or the $\mathbf{3 5 . 7}$ million US Americans who live alone $-28 \%$ of households. COVID-19 is forcing us to rediscover what it means to be alone together, separate but supportive, with a new sense of needing each other that blocks the rampaging individualism of the past century. The \#MeToo generation is, post-COVID, becoming more the \#MeWe and \#WeToo generation

The opposing allures of socialness and solitude, of connection and isolation, are Siamese twins of health and holiness. Jesus himself swung from society to solitude, often from one extreme to another. Socialness is when you look into the faces of others, but solitude is not when you look at your own face, or look in the mirror, or seek yourself, but when you seek God's face and see yourself there.

The power of touch, the importance of touch, has been revealed never to be repealed. In spite of a governmental edict, 'This is your government talking ... Don't touch another person,' we are experiencing the meaning of skin hunger, which is even more a psychological than a physiological event. How deep the need for human touch can go is evidenced in studies of infants who, when not touched or hugged, can even die

We have yet to explore how to experience touch during physical distancing. Can we learn to give and receive a new 17.1 am borrowing this phrase from the short-lived GE executive John Flannery. 
touch to satisfy our skin hunger? Colleague Joe Myers suggests we look at tools like the five love languages and reframe them as the five touch languages. However, as Myers has already shown in his classic study of small groups within the context of proxemics (Myers 2003), these touch languages need to take place within the four spaces in which relationships form: personal, social, public, and intimate. Neuroscience seems to suggest all four relational spaces can be experienced online with the same chemical releases, the same interaction triggers and, thus, the same experience as face to face. Whether humans have matured the tools for our minds to accept what the brain is processing is another matter. What is almost assured is that touch may be the most prized human interface of the future.

\section{Christianity is becoming a GOOD religion again, where GOOD means get out of doors, and is 'building back greener'}

For some reason, the coronavirus does not hit Africa and Asia like the industrialised countries. Vietnam, for example, has experienced zero deaths. No one knows why. Perhaps Asians and Africans have great ventilation because they live in the great outdoors without windows.

One of the effects of the COVID-19 pandemic on Church-21 is to make us more aware of the natural world and the place of humanity within it. There is underway a rediscovery of creation and the importance of the blue dome under which we all live. ${ }^{18}$ COVID-19 has forced Church-21 to take the blinders off so we can see our degraded ecosystems and the devastations of human failure to fulfil our Prime Directive: 'tend and till the garden' (Gn 2:15).

There is a Moroccan tale called The Birth of the Sahara where, in this fable, each grain of sand in The Great Desert represents a lie told by a human. The oases are traces of the garden that once covered the earth before the death of innocence (cf. Hamilton 2012). The good news is that in this short amount of pandemic time, the Earth is springing back quickly to life and the lies lifted. Can we literally turn planet Earth back into a garden? Can there be a new rewilding of the planet?

All outdoor activities are now a boon, but gardening has become one of the hottest new trends and the number one hobby during the pandemic, even eclipsing cooking or reading. The Economist reports in its 'The World in 2021' issue that 'Britons of every generation prized a private garden above all other features of a home, including secure locks and a good internet connection' (The Economist 2020b:71). Already between eight and nine in every ten Britons have a private garden, and the viewership of prime time flower shows is skyrocketing (The Economist 2020c:44). Just try and find some seeds or buy a shed or reserve some camping space. There are more boats in the waters off the San Juan Islands than in the last 30 years. We could take up the rest of the essay citing example after example of horticultural therapy.

18.According to Jonathan Tulloch, 'Scientists are already pointing out that the lack of emissions in lockdown China saved many more lives than the 3297 that officia numbers say died of the virus' (Tulloch 2020:9).
Want to practice faith, especially faith in the future? Learn the world's oldest profession - gardening. Plant some flat dull seeds into the dark dirt out of trust that sun and rain will miraculously change buried seeds into iridescent, colourful, shimmering flowers. That's the healing power of the garden:

Humanity is waging war on nature. This is suicidal. Nature always strikes back - and it is already doing so with growing force and fury. (Antonio Guterres, Secretary General of the United Nations; cf. Harvey 2020)

\section{The church is entering an age of innovation and imagination: The epiphytic church}

Crisis can catalyse innovation. Cracks open a universe of possibilities. They make us relook at life 'with [our] mind ajar', as the poet Elizabeth Jennings liked to put it (Jennings 1987). Times like these take away all our excuses for resisting change. They force us to use our right brains to find new ways and forge new pathways to doing life and church again. They push us mentally to read more, think more, imagine more, and hope more. About the only thing that can bring down an oligopoly is a swarm. And crises can catalyse swarms of entrepreneurs to crawl over the monsters and bring them down to earth.

For a long time, the church in the West, rather than bristling with energy and entrepreneurship, has been stuck in a dead zone of reductive imagination. The globalisation of triviality and superficiality has covered the church from one theological pole to the other. The COVID-19 pandemic is yanking the church out of its stuckness in the status quo and kick-starting some creativity and imagination for the Jesus mission of high expectations, big thrills, and expansive dreams. Crisis can be a shock treatment that exposes our bad default settings and opens us up to resets and reboots for new encounters with burning bushes, smoking mountains, and eureka lightbulbs.

When Mount Tambora erupted in April 1815, the dust and ash from the volcano (in what is now Indonesia) blotted out the sun and lowered global temperatures, hurting harvests everywhere. 1816 is called by historians 'the year without a summer'. As food prices soared, tens of thousands of people died from famine and disease. So did thousands of horses because their owners could no longer afford to feed them oats and used them as food. It was against this dismal backdrop that Karl von Drais, a German inventor, dreamed up in 1817 the 'Laufmaschine' to replace equine locomotion. Today his 'running machine' is known as the bicycle.

Calamities can spur innovation. Creative disruption can stimulate new ways to innovate. However, new occurrences require new thinking, new frameworks, new metaphors, and new narratives, not that repudiate the old, but that build on the old to create something old-new, ancient-future. 'What will get you there is not what brought you here', to paraphrase the famous Henry Fordism. Jaded strategies and jejune stories will not take us forward. It is time to rethink the world. But if such rethinking and rebuilding are not enlightened and 
enlivened by the recognition of a transcendent reality, human life will falter and stumble.

This is an apocalyptic moment, not doom and gloom, but boom and bloom and zoom, an unveiling and revealing of the heavenly realms that may have been hidden before this unveiling. It is time to rethink the church - time to rethink the world. We're in a new place, so we should take our shoes off (which God told Moses when he recognised the burning bush), roll our sleeves up, and let our imagination loose.

A very unusual tree grows between Casorzo and Grana, Italy, or rather, an unusual pair of trees known as The Double Tree of Casorzo. It consists of a cherry tree growing on top of a mulberry tree, creating a kind of two-tiered, two-species hybrid duplex. While it is not uncommon for a small tree to grow on a larger one - 'resurrection trees', the configuration is called - it has been rare to see epiphytical growing trees, two fully grown trees doing so well together with the cherry tree on top bearing lovely white flowers.

The Epiphytic Church is one model and metaphor of what is next: a new different tree growing on top of an old tree. The Epiphytical Church will witness more than cherry trees growing on top of mulberry trees of difference piled upon difference. The wisdom and wealth of creativity and innovation are best developed in places where there is plenty of openness, opposition, and difference. It matters less what that difference is than that there is difference. At the bottom of the ocean, there is no light. What there is, is life without light. How? There's difference. The difference in the ocean depths is thermal heat, not light. Indeed, five km down there is more life than five $\mathrm{km}$ up.

In a small town, if there is only one lawyer he will starve. If there are two, both will do well. (Abraham Lincoln)

Many of our tribes today tend to be closed systems. The number of denominations that are open to listening to people from outside that denomination is shrinking. COVID-19 is forcing open systems of exchange of ideas and dialog among those with widely different views on every subject.

For creativity to live and flourish, reality distortion fields are required. Ideas are life forms, and more so as they become self-generative. Molecular biologist, James Watson, who along with James Crick and Rosalind Franklin unravelled the genetic code, defined life as 'a pattern of information that is capable of self-reproduction'. There is not much difference between an idea and a life form, a meme and a gene. ${ }^{19}$ You advantage wisdom's growth by keeping the system open, asymmetry, and swatting down the hive mind, however and wherever it appears.

There is another inalienable right the founders of the Constitution did not talk about. We have a right to know. More than that, the idea should have its own franchise. The idea has a right to be known (See, songwriter Barlow 1994).

19.Biologist Dawkins (1976) makes this assertion and calls ideas 'memes.'
The masks are unmasking us, forcing us in a kind of Sadomaskism to confront the invisible masks we've been wearing when we go out and especially when we go to church

Everyone is having trouble getting used to a world of masked-faces and six-foot spaces. However, how long have we been wearing masks? Really? Especially to church? Really? We are now needing to rip off our masks and be real with each other and will be increasingly obsessed with real you, real church, real followers, real Christianity.

COVID-19 forced us to live in a world in hiding, a world behind masks, ${ }^{20}$ but maskism just revealed our number one problem after the fall: We are hiders. We are not seekers. God is the seeker. We are the hiders. God's first question after the fall was, 'Where are you?' or 'Where are you hiding?'

God is seeking God's church in its favourite hiding places, calling the church out of its caves and cocoons and showing the church where its only true hiding place is: in the cleft of the Rock, in the arms of Jesus. When a crisis brings the world to a stop, what will start it up again? Who will put the spin back into our world? Will the church say: Jesus! Let the church say, as it once said: Jesus can jump-start any heart, even when it is closed in, locked down, and motionless. God can take the most dread-filled virus that drives nations to shutter the planet and turn it into creative energy that can triumph over the disease and usher humans into higher spiritual enlightenment.

With this unmasking of the church seems to be coming a renewed sense of the comfort of the Holy Spirit, perhaps even a coming Age of the Spirit. Only the Spirit can 'comfort' in times like these, a time of 'Holy Spirit Rain Down' unlocking of the 3M's of the Spirit: Mystery, Magic, and Miracle. With our mouths closed and ears open, perhaps there can be heard the death rattle of The Rule of St. Roberts (Roberts Rules of Order) and the baby rattles of St. Paul's Rules of the Spirit. What if the church were 'ordered' no longer by the Order of St. Roberts but the Order of the Holy Spirit?

\section{COVID-19 is pushing dinosaurs out at every door, in every domain, even the educational arena. What African-American educator and civil rights activist, Samuel D. Proctor (1921-1997), predicted long ago, may be on the horizon: We will someday discover that 'education is the cultivation of imagination' (Proctor \& Taylor 1996:29-30)}

Both academia and the church have been working off an educational model created by the Prussians during the Industrial Age. The bankruptcy of this 'Big-Jug, little-mug' model of learning can no longer be denied or blocked. No authority figures are needed anymore to access information,

20.1 personally think that one day we will look back on all this mask-wearing in the same way we look back on children in the 50 s and 60 s being forced to hide under their desks in duck-under-your-desk drills ... to protect them if an atom bomb was dropped. 
but they are desperately needed to process and assess information and turn information into knowledge, wisdom and truth. Every person now has access to all the learning of the world, but how do we assess what is fake and real information and how do we process that information into transformation? We need mentors more than ever.

Edmit, a college planning consulting business, estimates that 'a third of American private colleges are on the course to run out of money within six years.' The dramatic drop in international enrolment is a brutal blow to higher education. In Australia, foreign students provide a quarter of all the universities' income. COVID will cause a drop in income for universities of at least 20\%. Harvard has a 41.9 billion endowment but recorded a 10 million deficit in 2020. Some 300000 college-related jobs have been eliminated across the United States by December 2020.

With schools forced to adapt and adjust, the opposition to online education or 'distance learning', once condemned by faculties as 'glorified correspondence schools', will end. All faculty are now virtual faculty. Once remote learning is embraced fully, faculty will design and develop new methods of online learning that will move higher education in unimagined directions, especially hybrid models of education that integrate in-person components and live students plus a virtual component with online participants, optimising learning for both face-time and face-to-face students.

Faith means we live life forward. We learn from the past but lean into the future. Jesus pushes us from the past but pulls us from the future into the future and beckons us to join him in what he is already doing there. Jesus is always ahead of us. Gregory of Nyssa insisted that faith goes from beginning to beginning for all eternity. 'Such a fast/God, always before us and/leaving as we arrive' is how Welsh poet/priest R.S. Thomas puts it in Pilgrimages. We romance the dance and glance of God's back, as Moses did on the mountain:

The learning process and the creative process ... once reserved for scholars and geniuses, we now know to be a character of all human perception. (McLuhan 1956:9)

Part of the new learning is the acquisition of grammatical proficiency in graphicacy (audio-visual media) as well as literacy (print media). As early as 1967, the most 'controversial' scholar of his day, Canadian philosopher Marshall McLuhan, claimed that the distinctions between 'in' and 'out' of school no longer applied:

Our place of learning is the world itself, the entire planet we live on. The little red schoolhouse is already well on its way toward becoming the little round schoolhouse.

The time was coming, if not already here, he argued, that 'the main "work" of the future will be education, that people will not so much earn a living as learn a living'. Lifelong learning is the main business of every business, no matter what that 'business' may be (McLuhan \& Leonard 1967:23-25).
The church is not a 'business', but McLuhan's prophetic call for 'lifelong learning' applies to the world of discipleship even more than any other 'business'. Every church is now a seminary ('seminary' literally means 'seed-bed' for faith), and every pastor a dean, yoking a common core of theological content for the 21st century to both customised mentoring and cohort-based, peer-to-peer (P2P) learning based on the world as both church and our classroom.

\section{The pandemic has destroyed the illusion that we were in control of our lives. Indeed, the 2020-2021 lockdown has been history's biggest rehab for control addicts}

COVID has been a glass-case exhibit in how you cannot control the story. If you think you can control the story, you have not read the story or you do not understand the story or your earth is flat. The Earth is moving. There is no stable place, no fixed point. The temptation to control, to manage, to organise, to 'plan' rather than to prepare for the mobility of the universe has been roundly rebuked by COVID. The church must learn preparedness models of movement rather than delusional planning models of control and security.

\section{A post-COVID world requires the church to read the story again from a new vantage point. Not that we can stockpile and be selfish, but so that we can reach out to others in healing, kindness and service}

When contexts change, the church must be prepared to fast forward the future, which is often found in a harking back and a taking back of the past from a backslidden present.

Before COVID, the world was stuck in a bad equilibrium. For example, working from home was less common than it should have been. Why all the two to three hour commutes per day when a lot of our work could have been done just as well from home? The glory days of the Main Street office and downtown skyscrapers are over. The TV series The Office (2005-2013) is an elegy to the days of the past. After all, does bringing people together at The Office foster more creativity, collaboration and innovation? Or does it promote idle chatter, watercooler gossip and tension? There is no more 'business as usual', as there is no more 'education as usual'.

In theological terms, 'Behold I do a new thing. Do you not perceive it?' (Is 43:19). What kind of a 'new thing' this cosmopolitan or cosmos-politan 'New World Order' will be, is uncertain. However, the front cover of The Economist featuring 'Goodbye Globalisation' is hasty and headless (The Economist 2020a:7). The unitary nation state will continue to collapse and crumble, as the assumption that the nation state is the only expression of legitimate government wanes and weakens and city-states, stateless nations and fractal governance emerge.

A whole new 'globalised world' will be different from the one we are used to or dreamed of. So much for 'open borders'. 
The lockdown has sealed borders and restricted travel to the point where $90 \%$ of the people in the world live in countries with mostly closed borders (The Economist 2020a:7). Tourism, the number one industry in the world, has been devastated by the pandemic with a $50 \%$ decline in travel at best. Our plenitude of problems is now either very local or completely global. Our factional, fractious world makes solving global problems harder, while geopolitical instability will be the enduring backdrop of the missional context for the future.

In philosophical terms, we are in the midst of a 'paradigm shift' - a phrase popularised by physicist and philosopher Thomas Kuhn in The Structure of Scientific Revolutions (Kuhn 1962). The phrase 'paradigm shift' has given way to other metaphors like 'disruptive technology' and 'black swans'. However, all these phrases are getting at the same thing: when a new metaphor or mode of thinking or even a thing replaces your old metaphors or thinks or things, hold on to your seat because everything goes back to zero, and the days of 'best practices' are over.

When things go back to zero, everything needs not transformation but transfiguration, in the Latinate sense that transfigurare means 'to change the shape of'. Like a dead tree once 'transfigured' takes the shape of chairs and desks and pipes and chess sets, so too what emerges from going back to zero is something new and not conventional. It is time to turn off the computer, reboot the OS and start it up again. It is time for a transfigured church. No more remodelling, only renovation and innovation! Back to the studs and let the Spirit build her house - or sometimes even, raze the church and tend the garden and its inhabitants. Trust God for the increase.

\section{Rebirth of the Catacomb church, cellular spirituality, and new monastic mentalities}

This seems like a strange 'blessing', but COVID spells the end of the Constantinian captivity of the church and the collapse of Christendom, two of the worst things that ever happened to Christianity.

There are no culture Christians anymore. If you go to church today, whether you are young or old, it is because you want to be there, not because you are 'supposed' to be there, or it is socially advantageous to be there. The days of the disengaged Christian or 'anonymous Christian' are over. The days of the church as a preferred backdrop for weddings, funerals, life events or even worship itself are over. The Christian religion is disappearing from western societies.

Even kids 'raised in the Church' do not want to get married in church, or as one young adult phrased it when her parents wanted a church wedding: 'Ewww ... That's so lame and old.' As of 2017, only $22 \%$ of US Americans had their wedding in a religious house of worship, which was down from $41 \%$ in 2000. Thirty per cent $(30 \%)$ now say they do not want a religious funeral when they die (cf. Burton 2020). In one of the states where there is still a residual memory of Christianity
(Alabama), a legal marriage requires no ceremony, no witnesses, no officiant, only a notarised signature on a document. Anyone can 'officiate' at any wedding because it is not really a legal occasion or an official occasion. It is only ceremonial: ${ }^{21}$

Our world is dominated by several great religious systems, whose differences seem to be coming to the fore with increasing sharpness and setting the stage for innumerable political and armed conflicts. In my opinion, this fact - which is attracting, understandably, a great deal of media attention - partly conceals a more important fact: That the civilization within which this religious tension is taking place is, in essence, a deeply atheistic one. Indeed, it is the first atheistic civilization in the history of humankind. (Havel 1999:ix)

In a changing cultural climate where 'going to church' is no longer the norm, some are already fearing that the public profile of the church, like that in Ireland, is diminishing to 'the point of virtual invisibility' (MacDonald 2020:31). Elites throughout Europe and North America have already made the transition to mockery and contempt. One of the most respected philosophers in the late 20th century, political philosopher Thomas Nagel, in his The Last Word (Nagel 1997) writes:

I want atheism to be true and am made uneasy by the fact that some of the most intelligent and well-informed people I know are religious believers. It isn't just that I don't believe in God and, naturally, hope that I'm right in my belief. It's that I hope there is no God! (p. 130)

One anti-Christian polemic against 'stupid' Christians, which even fails as a polemic, got the Book of the Year Award from The Telegraph, The Spectator, The Observer, BBC History Magazine and was a New York Times Notable Book and a New York Times Book Review Editors' Choice. Filled with spurious assertions, jaw-dropping non-sequiturs and historical errors, arts journalist Catherine Nixey's The Darkening Age: The Christian Destruction of the Classical World (Nixey 2019) bludgeons Christians for murder, mayhem, repression, and the destruction of classical literature. Historian Adrian Hastings concluded a review of a book riddled with cheap shots at Christianity, 'even Christians deserve a measure of fairness' (Hastings 2000:28).

When you come out into the open, profess your faith, and practise your Christianity, you will now pay a price. You cannot insult and injure anyone, that is, except Christians. In one June 2020 weekend in Boston, two Catholic Churches were set on fire, and two statues of the Virgin Mary were damaged. This story was replicated that same month in Florida, Los Angeles, San Francisco and New York City (Heneghan \& Luxmoore 2020:28). An average of three places of worship are desecrated daily, and that does not include cemeteries, statuaries, and other Christian symbols (Luxmoore \& Heneghan 2020:27).

21.Thomas Hardy, the English poet and novelist, wrote a novel called The Woodlanders (Hard 1887) that seems almost inconceivabe today. The plot line revolves around a ward 1887) that seems almost inconeivable today. The plot in a wedding that will not take place if the girl can't be married in a church, which her fiancé (a physician) wants no part of. So she calls off the marriage until he submits to her terms of a church wedding. 
The same is happening around the world. Physical attacks on Christians in France have quadrupled, with numbers of Christians now asking to be 'de-baptised' and with only $4 \%$ of self-identifying Catholics in France attending Sunday mass. ${ }^{22}$ There were 30000 Catholic priests in France at the turn of the 21st century. In 2015, the number of active priests was 5800. Religious freedom for Christians has been declining rapidly since 2013: 'More than 340 million Christians suffer high levels of persecution and discrimination for their faith, one in eight worldwide' (OpenDoors 2021).

It will not be easy for the 'chosen people' to learn to live with the indifference of the world at best, much less its hatred and mockery. Christians who practise their faith openly will live under a nimbus klieglight of public surveillance. They will be punished for bringing beauty, goodness and truth to humanity, just as Prometheus was punished for bringing fire. In the new global morality, just as in the early church, Christians are regarded as the immoral ones - atheists (Christians only believed in one God), cannibals (who else eat 'flesh' and drink 'blood'?), incestuous and immoral ('love feasts' took place at night in the secrecy of one's homes), etc. ${ }^{23}$

Sometimes the right side of truth is not the right side of history. Sometimes being on the wrong side of history is getting on the right side of truth. This grating between truth and history may return the church to the battlefields, barriers, or the catacombs. ${ }^{24}$ Or maybe our homes will incubate a new monasticism where we learn to be apart, together; where we particularise in order to globalise. What if a new monastic missional order was founded where the 'monastery' was understood as the world? Here is Bonhoeffer (1990):

The restoration of the church will surely come only from a new type of monasticism which has nothing in common with the old but a complete lack of compromise in a life lived in accordance with the Sermon on the Mount in the discipleship of Christ. I think it is time to gather people together to do this. ${ }^{25}$

On the outskirts of Rome, there are more than 500 miles of underground cemeteries in 60 different catacombs. Most were plundered and destroyed in the 8th century, but some inscriptions remain that were painted by the oldest of Christianity's 'professionals': fossores. The fossores combined three roles in one: gravediggers, priests, and artists who painted images on walls of the tombs. Of the many notable features of these early Christian inscriptions, three missional standouts cry out for attention.

22.Two-thirds of the French people self-identify as 'Catholics'. Yet less than $5 \%$ (closer to $4 \%$ ) attend mass every week. In French, the difference is known as 'zombie Catholicism', 'Christian atheism', and 'anonymous Christians'.

23.Prime Minister Pedro Sanchez's Spanish Socialist Worker's Party, which in 2020 is governing Spain, has a legislation it is introducing in 2021 to allow 'a dignified death and euthanasia' at public expense as well as the public appropriation and recovery of all 'assets improperly registered to the church' (whatever that means).

24.The US editor and conservative Rod Dreher believes 'we now live under the heel of the "soft totalitarianism" of what he calls the pink police state' (Dreher 2020). I am outlining a different option than the one portrayed in Dreher (2017).

25.This is an extract of a letter written by Bonhoeffer to his brother Karl-Friedrick on 14 January 1935
Firstly, they almost always draw from biblical narratives. The first Christians lived out of a storied imagination straight from the Scriptures: fish, vine, shepherd, baptism symbolised by Moses striking the rock, loaves and fishes, bread and wine, Lazarus or Jonah (resurrection), Noah's ark, Isaac, Daniel (deliverance from danger and persecution), paralytic carrying cot (forgiveness of sins and intercessory prayer) and a banquet of food (heaven). Their identity was forged on the anvil of the Jesus narrative, and these catacomb Christians displayed a Rock-hard identity.

Secondly, early Christian art is filled with personal references some in Greek, some in Latin, some both - as if the person is speaking. Every person has a voice, and most graves have a little niche where personal items that showcased their personal values and virtues were buried with them. A catacomb identity that is by nature communal, actually strengthened the uniquely personal (cf. also Sweet 2014).

Thirdly, a unique trademark of these catacomb Christians was an accent on hope: hope of resurrection and hope of heaven. Noticeably absent are negative portrayals of the powers-that-be and their persecutions. Perceptible were the affirmation of hope in the future. There is more to being a disciple than having faith. There is more to being a disciple than showing love. There is hope. The first Christians did not forget hope. They always hoped, even in the worst of times.

Hopelessness is the acid rain of faith, the nuclear winter of the Spirit. At the end of the 20th century, Time magazine named Steven Spielberg the most influential person of his generation. In 2006, Spielberg received the Kennedy Center Honors for lifetime achievement and was asked by Liam Neeson, 'What is your favorite ending?' Spielberg replied, 'Hope' (Morse 2008).

When people start seeing mushroom clouds swelling out of the Scriptures, they run for cover, not from the Scriptures, but from those working the fog machines. 'He is the Way', writes the poet W.H. Auden, 'Follow Him/through the Land of Unlikeness; You will see rare beasts/and have unique adventures' (Auden 1944).

Maybe a catacomb mentality will make being a Christian less an agenda and more an adventure, less about rules and more a romance ${ }^{26}$ less a programme of action and more a pathway of mission, less and less fear-filled (fight, flight, or freeze) and more a faith-filled focus on Christ, less a tailoring of expectations to realities and a succumbing to the temptation of 'unhope', and more a 'hope against hope' for the impossible, the unreasonable, and the heavenly.

\section{Acknowledgements Competing interests}

The author declares that he has no financial or personal relationships that may have inappropriately influenced him in writing this article.

26.1 borrowed this phrase "less about rules and more a romance" from colleague and friend David Sanford. 


\section{Author's contributions}

L.S. is the sole author of this article.

\section{Ethical considerations}

This article followed all ethical standards for research without direct contact with human or animal subjects.

\section{Funding information}

This research received no specific grant from any funding agency in the public, commercial or not-for-profit sectors.

\section{Data availability}

Data sharing is not applicable to this article as no new data were created or analysed in this study.

\section{Disclaimer}

The views and opinions expressed in this article are those of the author and do not necessarily reflect the official policy or position of any affiliated agency of the author.

\section{References}

Auden, W.H., 1944, For the time being: A Christmas oratorio, Princeton University Press, Princeton, NJ.

Barlow, J.P., 1994, 'The economy of ideas', Wired, January 03, 1994, viewed 31 January 2021, from https://www.wired.com/1994/03/economy-ideas/.

Bonhoeffer, D., 1990, 'Extract of a letter written by Bonhoeffer to his brother KarlFriedrick on 14 January 1935', in D. Bonhoeffer, G.B. Kelly \& F.B. Nelson (eds.), A Testament to freedom: The essential writings of Dietrich Bonhoeffer, p. 424, Harpercollins, New York, NY.

Brooks, D., 2019, The second mountain: The quest for a moral life, Random House, New York, NY.

Burton, T.I., 2020, Strange rites: New religions for a godless world, Public Affairs, New York, NY.

Christakis, N., 2020, Apollo's arrow: The profound and enduring impact of the coronavirus on the way we live, Little, Brown, Spark, New York, NY.

Dalton, A., 2020, 'Optical communications and the internet of neuroelectronics adventures in pushing the limits', Podcast, March 06, 2020, viewed 25 April 2021 from https://www.eejournal.com/fish fry/optical-communications-and-theinternet-of-neuroelectronics/.

Dawkins, R., 1976, The selfish gene, Oxford University Press, Oxford.

DePaulo, B., 2015, How we live now: Redefining home and family in the 21st century, Atria Books, New York, NY.

Dodd, L., 2020, 'Post-COVID ambivalence about returning to church buildings', The Tablet, September 19, 2020, viewed 25 April 2021, from https://canonesses.co. uk/wp-content/uploads/2020/12/The-Tablet-article-10-Sep-2020.pdf.

Dreher, R., 2017, The benedict option: A strategy for Christians in a post-Christian nation, Sentinel, New York, NY.

Dreher, R., 2020, Live not by lies: A manual for Christian dissidents, Sentinel, New York, NY. Eusebius, 2004, Ecclesiastical history, transl. C.F. Cruse, Hendrickson Publishers, Peabody, MA.

Gecewicz, C., 2020, 'Few Americans say their house of worship is open, but a quarter say their faith has grown amid pandemic', Pew Research Centre, April 30, 2020, viewed 30 May 2020, from https://www. pewresearch.org/fact-tank/2020/04/30/ viewed 30 May 2020, from https://wwW.pewresearch.org/fact-tank/2020/04/30/ few-americans-say-their-house-of-worsh
religious-faith-has-grown-amid-pandemic/.

Hamilton, R., 2012, The last storytellers: Tales from the heart of Morocco, IB Tauris, London.

Hardy, T., 1887, The woodlanders, MacMillan, London.

Harvey, F., 2020, 'Humanity is waging war on nature', The Guardian, December 02, 2020 viewed 30 March 2021, from https://www.theguardian.com/environment/2020/ $\mathrm{dec} / 02 /$ humanity-is-waging-war-on-nature-says-un-secretary-general-antonioguterres.

Hasley, R., 2020, Everything is gonna be all right: Devotionals for faith and encouragement, Invite Press, Plano, TX.

Hastings, A., 2000, 'A slant on the church', Times Literary Supplement, November 17, 2000, p. 28.
Havel, V., 1999, 'Introductory essay', in S. Abdullah (ed.), Creating a world that works for all, pp. viii-xiv, Berrett-Koehler, San Francisco, CA.

Honigsbaum, M., 2020, The pandemic century: A history of global contagion from the Spanish Flu to COVID-19, WH Allen, London.

Intel Newsroom, 2020, 'Intel, MIT and Georgia tech deliver improved machineprogramming code similarity system', Intel News-Byte, July 29, 2020, viewed 02 October 2020, from https://newsroom.intel.com/news/intel-mit-georgia-techmachine-programming-code-similarity-system/\#gs.q7a2cq.

Jennings, E., 1987, 'In praise of creation: Poem. In Gilbert, SM, Jennings is a woman who can write a really glowing line', Poetry Prof, viewed 30 April 2021, from https://poetryprof.com/in-praise-of-creation/.

Kuhn, T., 1962, The structure of scientific revolutions, University of Chicago Press, Chicago, IL.

Levy, B.-H., 2020, The virus in the age of madness, Yale University Press, London.

Levy, D. \& Garfield, B., 2012, 'Forget product positioning: This is the dawn of the relationship era', Course Hero, January 02, 2012, viewed 30 January 2021, from relationship era, Course Hero, January 02, 2012, viewed 30 January 2021, from
https://www.coursehero.com/file/10209286/Ignore-the-Human-Element-ofhttps://www.coursehero.com/f

Luxmoore, J. \& Heneghan, T., 2020, "French church urged to act against "constant" attacks', The Tablet, August 01, 2020, viewed 30 September 2020, from https:// www.thetablet.co.uk/news/13190/french-church-urged-to-act-against-constantattacks-.

MacDonald, S., 2020, 'Church income "in freefall"', The Tablet, September 12, 2020 viewed 02 October 2020, from https://www.thetablet.co.uk/news/13344/churchincome-in-freefall-

Matthew, T.F., 1999, The clash of gods: A reinterpretation of early Christian art, rev. and exp. edn., Princeton University Press, Princeton, NJ.

McLuhan, M., 1956, New media in arts education, An address given at the March 1956 convention of the Eastern Arts Association, New York, NY.

McLuhan, M. \& Leonard, G.B., 1967, 'The future of education: The class of 1989', Look Magazine, February 21, 1967, pp. 23-25.

Moore, C., 2020, Built for this, Tribl Records, Atlanta, GA.

Morse, M., 2008, Making room for leadership: Power, space and influence, IVP Books, Downers Grove, IL.

Myers, J.R., 2003, The search to belong: Rethinking intimacy, community, and small groups, Zondervan, Grand Rapids, MI.

Nagel, T., 1997, The last word, Oxford University Press, New York, NY.

Nixey, C., 2019, The darkening age: The christian destruction of the classical world, Mariner Books, Boston, MA.

OpenDoors, 2021, World watch list 2021: The top 50 countries where Christians experience the most persecution, viewed 17 November 2020, from https://www. opendoors.org.za/christian-persecution/world-watch-list-2021/.

Proctor, S.D. \& Taylor, G.C., 1996, We have this ministry: The heart of the pastor's vocation, Judson Press, King of Prussia, PA.

Robertson, T., Carter, E.D., Chou, V.B., Stegmuller, A.R., Jackson, B.D., Tam, Y. et al., 2020, 'Early estimates of the indirect effects of the COVID-19 pandemic on maternal and child mortality in low-income and middle-income countries: A modelling study', The Lancet 8(7), e901-e908. https://doi.org/10.1016/s2214109x(20)30229-1

Rosen, M., 2021, Many different kinds of love: A story of love, death and the NHS, Ebury Press, London.

Savanta: ComRes, 2020, Tearfund COVID-19 prayer public omnibus research, viewed 31 May 2020, from https://comresglobal.com/polls/tearfund-covid-19-prayerpublic-omnibus-research/.

Scott, L., 2015, The four-dimensional human: Ways of being in the digital world, WW Norton, New York, NY.

Stark, R., 2011, The triumph of Christianity: How the Jesus movement became the world's largest religion, Harper Collins Publishers, New York, NY.

Sullum, J., 2009, 'Hawk in hock', American News Digest: The Patriot Post, May 12, 2009, viewed 25 April 2020, from https://patriotpost.us/opinion/2046-hawk-inhock-2009-05-13.

Sweet, L.I., 1994a, Faithquakes, Abingdon Press, Nashville, TN.

Sweet, L.I., 1994b, Health and medicine in the evangelical tradition: Not by might nor power, Trinity Press, New Delhi.

Sweet, L.I., 1999a, SoulTsunami: Sink or swim in new millennium culture, Zondervan, Grand Rapids, MI.

Sweet, L.I., 1999b, Aqua church: Essential leadership arts for piloting your church in today's fluid culture, Loveland Colorado Group, Loveland, CO.

Sweet, L.I., 2000, Postmodern pilgrims: First century passion for the 21st century world, B\&H Publishing, Nashville, TN.

Sweet, L.I., 2001, Carpe Mañana: Is your church ready to seize tomorrow?, Zondervan, Grand Rapids, MI.

Sweet, L.I., 2008, The church of the perfect storm, Abingdon Press, Nashville, TN.

Sweet, L.I., 2012, Viral: How social networking is poised to ignite revival, WaterBrook Press, Colorado Springs, CO

Sweet, L.I., 2014, Me and we: God's new social gospel, Abingdon Press, Nashville, TN.

Sweet, L.I., 2019, Rings of fire: Walking in faith through a volcanic future, NavPress, Colorado Springs, CO. 
Sweet, L.I. \& Beck, M., 2021, Contextual intelligence: Unlocking the ancient secret to mission on the front lines, Fresh Expressions, Richmond, VA.

Sweet, L.I., McLaren, B.D. \& Haselmayer, J., 2003, “' $A$ ” is for abductive: The language of the emerging church, Zondervan, Grand Rapids, MI.

Tainter, J., 1990, The collapse of complex societies, Cambridge University Press, Cambridge.

Taleb, N.N., 2007, The black swan: The impact of the highly improbable, Penguin Books, London.

The Economist, 2020a, 'Goodbye globalisation: The dangerous lure of self-sufficiency', The Economist, May 16, 2020, viewed 17 November 2020, from https://www. economist.com/weeklyedition/2020-05-16.

The Economist, 2020b, 'The world in 2021', The Economist, November 2020, viewed 11 January 2021, from https://www.economist.com/the-world-in-2021.

The Economist, 2020c, 'A nation of gardeners', The Economist, May 02, 2020 viewed 30 September 2020, from https://www.economist.com/britain/2020/ 05/02/a-nation-of-gardeners.
The Economist, 2020d, Two leading economists disagree about the flagging American Dream, The Economist, May 16, 2020, viewed 30 September 2020, from https:// www.economist.com/united-states/2020/05/14/two-leading-economistsdisagree-about-the-flagging-american-dream.

The Economist, 2020e, The pandemic may be encouraging people to live in larger groups, viewed n.d., from https://www.economist.com/international/ 2020/12/05/the-pandemic-may-be-encouraging-people-to-live-in-larger-groups.

Todd, A., 1983, A time to remember (the autobiography of a chemist), Cambridge University Press, Canbridge.

Tolkien, J.R.R., 1954, The lord of the rings, Book 1, Allen \& Unwin, London.

Tulloch, J., 2020, 'Nothing can ever be the same again', The Tablet, April 04, 2020, viewed 02 October 2020, from https://www.thetablet.co.uk/features/2/17807/ nothing-can-ever-be-the-same-again

Williams, R., 2021, Candles in the dark: Faith, hope and love in a time of pandemic, SPCK, London.

Woods, R., 2020, Digital ecclesiology: A global perspective, Network for New Media, Religion \& Digital Culture Studies, College Station, TX. 